\title{
8: 82552004-82553481
}

National Cancer Institute

\section{Source}

National Cancer Institute. 8: 82552004-82553481. NCI Thesaurus. Code C42242.

Physical location of FABP4_Gene 